\title{
Government guarantees and financial liabilities of state owned road transport companies in Croatia
}

\author{
ANTO BAJO Institute of Public Finance \\ JELENA PETRUŠIĆ Faculty of Economics and Business Zagreb
}

\begin{abstract}
The main objective of this paper is to provide an overview of the amount and the structure of financial liabilities and government guarantees made from $200 \mathrm{I}$ to $2 \mathrm{OI} 4$ to the state-owned road transport companies - Croatian Motorways Ltd. (HAC), Croatian Roads Ltd. (HC) and Rijeka-Zagreb Motorway Inc. (ARZ). By 2014 the government had almost entirely guaranteed the financial liabilities of these companies - the amount of government guarantees approximately equals the amount of the liabilities incurred. HC has from 2011 been included in the statistics of general government debt according to the Eurostat methodology, whereas in 2014 the liabilities of HAC and ARZ were retroactively included. Reclassification of these companies' debts into direct general government debt resulted in a growth of that debt. Analysis of guarantees is useful to provide more complete information about the amount of debt, the borrowing conditions and maturities of the road transport companies' liabilities.
\end{abstract}

\section{STATE OWNED COMPANIES FROM THE ROAD TRANSPORT SEGTOR}

Croatian Roads Ltd. is a state-owned company for the management, construction, reconstruction and maintenance of state roads. ${ }^{.}$The Company was incorporated and registered in the Commercial Court Register in 200I, based on the Government Decision on the distribution and transformation of the Croatian Roads Authority. In line with this decision two companies were formed - Croatian Motorways and Croatian Roads with the only founder being the Republic of Croatia.

Croatian Motorways Ltd. was established for the design, ordinary and extraordinary maintenance of highways and road facilities, toll collection, construction and maintenance financing and other activities related to the management of highways. HAC and HC compose financial statements in accordance with international accounting standards and the Act on Roads. According to the Act on

IAct on roads. Available at: http://www.zakon.hr/z/244/zakon-o-cestama 
Roads HC and HAC are required to apply capital approach (because they have a public good in their balance sheet), according to which they present their operating result as neither profit nor loss. ${ }^{2}$ The resulting difference between own income and expenditure incurred in the current fiscal year, is made up at the expense of public capital.

Rijeka-Zagreb Motorway Inc. was founded in 1997 and is fully owned by the state. The economic purpose of the company is the financing, construction, management and maintenance of the RijekaZagreb motorway and its road and ancillary facilities on the land of the road in the exercise of rights granted by the Concession Agreement. The concession was given to the Company for a period of 32 years and II months.

Restructuring and debt monetization of HAC and ARZ. In 2013 the partial restructuring of HAC and ARZ was performed based on the Restructuring program for the period 2012-2015 which was produced by HAC and the Ministry of the Sea, Transport and Infrastructure (HAC, 2OI2). The aim is to harmonize operations of the companies with European standards (changes in organizational structure, effective financial management, downsizing, introduction of a corporate business strategy) and preparation for the monetization of their part of the public debt through awarding concessions for the operation and maintenance of highways. In April 2013, Croatian Motorways Maintenance and Toll Payment (HACONC) Ltd. began to work as a subsidiary of HAC and merged with the newly-established company Rijeka-Zagreb Motorway Maintenance and Toll (ARZ-ON) Ltd. as a subsidiary of ARZ. At the same time ARZ and HAC remained owned by the state. The merger of ARZ-ON with HAC-ONC was registered in the Commercial Court in Zagreb on January 3I, 2 OI4.

\section{GOVERNMENT GUARANTEES TO ROAD TRANSPORT COMPANIES}

There are guarantees approved by the Government and those approved by the Parliament. The Government decides on the making of all government guarantees, other than state guarantees - which are approved by the Parliament at the recommendation of the Ministry of Finance. The Parliament adopts special decisions related to government guarantees issued in favour of international financial institutions such as the International Bank for Reconstruction and Development (IBRD), the European Bank for Reconstruction and Development (EBRD) and European Investment Bank (EIB) as well as for HC and HAC. These guarantees are not included in the annual limit on the issuance of state guarantees prescribed by the law on the execution of the state budget for a particular year.

From 200 I until 20I3, 80 guarantees amounting to HRK 56.7bn were granted to companies from the road transport sector. The largest number of guarantees issued in a particular year was 9 (totalling HRK $5.2 \mathrm{bn}$ ) in 2009, whereas the largest amount (HRK 8bn) of guarantees was approved in 20II. From 200I until 2013, the share of guarantees for the three companies in total guarantees granted to the transport sector was greater than $55 \%$. In 2004 and 2008, almost all the guarantees granted to the transport sector were related to road transport. In the last three years more than $60 \%$ of total guarantees were granted to companies from the road transport sector.

On average, government guarantees in the amount of around I.2\% of GDP are made yearly to the transport sector, most of it to companies from the road transport sector. Some of those guarantees have expired, i.e. companies have paid off part of their loan obligations.

\footnotetext{
${ }^{2}$ Companies that have public goods in their balance sheet use the capital approach for recording certain business activities. Capital approach involves two parallel records of a public good and own revenues and expenditures, as well as assets, liabilities and equity. Under this approach, if own revenues are not sufficient to cover the total expenditures, the difference is covered by the public capital. This also applies to the part of depreciation which can not be covered with own revenue, and financial expenditures. Excess of revenues over operating expenditures increases public capital, whereas the lack of revenues up to the amount of actually incurred operating expenditures is compensated for at the expense of public capital (it decreases public capital).
} 
The largest amount of guarantees was approved for HAC - as much as HRK 35.3bn, followed by HC with HRK II.4bn and ARZ with HRK IO.Ibn (Tab. 2).

\section{Table I.}

Overview of government guarantees approved to the road transport sector (in billion HRK) and share of guarantees to the road transport sector in total government guarantees and total transport (in \%) from 2001 until 2014

\begin{tabular}{|c|c|c|c|c|c|c|c|c|}
\hline & $\begin{array}{l}\text { Total } \\
\text { guarantees } \\
\text { approved } \\
\text { in billion }\end{array}$ & $\begin{array}{l}\text { Guarantees } \\
\text { approved } \\
\text { to the } \\
\text { transport } \\
\text { sector } \\
\text { in billion }\end{array}$ & $\begin{array}{l}\text { Guarantees } \\
\text { approved } \\
\text { to the road } \\
\text { transport } \\
\text { sector } \\
\text { in billion } \\
\text { (HC, HAC, } \\
\text { ARZ) }\end{array}$ & $\begin{array}{c}\text { Share } \\
\text { of road } \\
\text { transport } \\
\text { in total } \\
\text { guarantees } \\
\text { in } \%\end{array}$ & $\begin{array}{c}\text { Share } \\
\text { of road } \\
\text { transport } \\
\text { in total } \\
\text { transport } \\
\text { in \% }\end{array}$ & $\begin{array}{c}\text { Total } \\
\text { guarantees } \\
\text { approved } \\
\text { in } \% \text { of GDP }\end{array}$ & $\begin{array}{c}\text { Total } \\
\text { guarantees } \\
\text { approved } \\
\text { to the } \\
\text { transport } \\
\text { sector in \% } \\
\text { of GDP }\end{array}$ & $\begin{array}{c}\text { Total } \\
\text { guarantees } \\
\text { approved } \\
\text { to the road } \\
\text { transport } \\
\text { sector in \% } \\
\text { of GDP }\end{array}$ \\
\hline $2 \mathrm{OOI}$ & 7.7 & 4.5 & 3.4 & 43 & 74 & 4.0 & 2.3 & I. 7 \\
\hline 2002 & 8.4 & 5.6 & 3.9 & 47 & 70 & 4.0 & 2.6 & I.9 \\
\hline 2003 & 9.0 & 6.0 & 3.3 & 37 & 55 & 3.9 & 2.6 & I. 4 \\
\hline 2004 & 5.8 & 2.4 & 2.4 & $4 \mathrm{I}$ & 99 & 2.3 & 0.9 & 0.9 \\
\hline 2005 & 3.7 & 2.7 & 2.5 & 68 & 93 & I. 4 & I.O & 0.9 \\
\hline 2006 & 9.4 & 6.2 & 4.6 & 49 & 73 & 3.2 & $2 . I$ & I. 6 \\
\hline 2007 & 14.8 & 8.3 & 6.5 & 44 & 76 & 4.6 & 2.6 & 2.0 \\
\hline 2008 & 7.9 & 5.4 & $5 \cdot 3$ & 67 & 98 & 2.3 & I. 5 & I. 5 \\
\hline 2009 & 9.4 & 6.I & 5.2 & 56 & 86 & 2.8 & I. 8 & I. 6 \\
\hline $2 \mathrm{OIO}$ & 9.6 & 4.7 & 4.4 & 45 & 93 & 2.9 & I. 4 & I. 3 \\
\hline $2 \mathrm{OII}$ & IO. 3 & 9.4 & 7.9 & 76 & 84 & 3.I & 2.8 & 2.4 \\
\hline $2 \mathrm{OI} 2$ & 5.6 & 4.9 & 3.7 & 66 & 76 & I. 7 & I. 5 & I.I \\
\hline 2013 & 6.0 & 5.9 & 3.8 & 63 & 65 & I. 8 & I. 8 & I. 2 \\
\hline Total & I07.7 & 72.2 & 56.8 & & & & & \\
\hline
\end{tabular}

Source: Authors based on Ministry of Finance's data

Table 2.

Approved guarantees by companies from $200 \mathrm{I}$ until 2013 (in billion HRK)

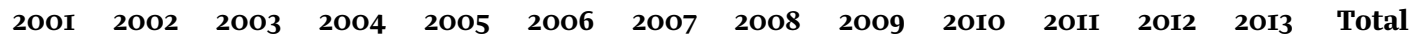

\begin{tabular}{|c|c|c|c|c|c|c|c|c|c|c|c|c|c|c|}
\hline $\mathrm{HC}$ & 0.4 & 0.0 & 0.6 & 0.2 & 0.6 & I. 2 & 0.5 & I. 2 & 0.8 & I. 4 & I. 2 & I. 8 & I. 5 & II.4 \\
\hline HAC & I. 3 & 3.0 & 2.7 & 2.2 & I.9 & I. 5 & 2.6 & 3.I & 3.4 & 2.9 & 6.8 & I.9 & 2.0 & $35 \cdot 3$ \\
\hline ARZ & I. 6 & 0.9 & 0.0 & 0.0 & 0.0 & I.9 & 3.3 & I.O & I.O & 0.0 & 0.0 & 0.0 & 0.4 & IO.I \\
\hline Total & 3.4 & 3.9 & 3.3 & 2.4 & 2.5 & 4.6 & 6.5 & 5.3 & 5.2 & 4.4 & 7.9 & 3.7 & 3.8 & 56.8 \\
\hline
\end{tabular}

Source: Authors based on Ministry of Finance's data

The Republic of Croatia almost fully guarantees the liabilities of all three companies. Therefore, the analysis of state guarantees can reveal the picture of borrowing conditions, potential risks, maturity of credits and loans that are granted to publicly owned companies by both domestic and foreign commercial banks and international financial institutions (EIB, EBRD and IBRD).

\section{FINANGIAL LIABILITIES AND GOVERNMENT GUARANTEES FOR ROADS}

From the data contained in financial statements it can be seen that the financial liabilities (mainly loans) of publicly owned road transport companies rose from HRK 32.5bn in 2009 to HRK 38.9bn in 2013 (from 
9.8 to II.8\% of GDP). The largest increase was recorded in the financial liabilities of HC, of about HRK 4bn, and in those of HAC, of HRK 2.6bn. The financial liabilities of ARZ are gradually declining.

Table 3.

Total financial liabilities of companies from 2009 until 2013 (in billion HRK and \% of GDP)

\begin{tabular}{|c|c|c|c|c|c|}
\hline & 2009 & 2010 & $20 I I$ & 2012 & 2013 \\
\hline Rijeka-Zagreb Motorway & 7.7 & 7.7 & 7.6 & 7.3 & 7.3 \\
\hline Croatian Motorways & 19.9 & 21.0 & $2 \mathrm{I} .5$ & 22.5 & 22.7 \\
\hline Croatian Roads & 4.8 & 5.9 & 6.8 & 7.8 & 8.8 \\
\hline Total & 32.5 & 34.5 & 36.0 & 37.5 & 38.9 \\
\hline$\%$ of GDP & 9.8 & IO.5 & IO.8 & II. 3 & II. 8 \\
\hline
\end{tabular}

Source: Authors based on data from companies' financial statements from 2009 until 2013

Total loan obligations of HC at the end of 2013 were HRK 8.8bn. Long-term liabilities were about HRK $8 \mathrm{bn}$, whereby the state has guaranteed for liabilities in the amount of HRK $7 \mathrm{bn}$ (loans and credits from EIB, IBRD and EBRD). The most critical period for HC are the next four years when almost half of its loan obligations - HRK 4.5bn becomes due (see Tab. 3.I. in Appendix).

In the next five years almost HRK I8bn of loan obligations become due for HAC, nearly HRK 5 bn during 2014 alone (see Tab. 3.2. in Appendix).

Out of HRK 8.8bn in 20I3, ARZ paid off only HRK I.5bn of loans, and the company still faces debts in the amount of HRK 7.3bn. The company is illiquid; its long-term liabilities are $56 \%$ higher than total assets. The item "equity" is negative because ARZ managed to achieve a loss above the equity value. During 2OI4, loans in the amount of around HRK Ibn become due for ARZ, and in the next 5 years another HRK 2bn will fall due (see Tab. 3.3. in Appendix).

It should be noted that the largest portion of the road transport companies' liabilities is long-term, with variations that are generally associated with new borrowings with shorter maturities. More than $80 \%$ are long-term liabilities. HAC has a relatively unfavourable maturity structure of liabilities with shortterm liabilities accounting for more than $20 \%$. Total cumulative short-term liabilities of all companies together increased from HRK 3.7bn in 2009 to HRK 7.76bn in 2013.

Table 4.

The share of long-term in total financial liabilities from 2009 until 2013 (in \%)

\begin{tabular}{|c|c|c|c|c|c|}
\hline & 2009 & 2010 & $201 I$ & 2012 & 2013 \\
\hline Rijeka-Zagreb Motorway & 98 & 97 & 95 & 94 & 80 \\
\hline Croatian Motorways & 83 & 72 & 89 & 88 & 76 \\
\hline Croatian Roads & 95 & 92 & 84 & 90 & 90 \\
\hline Total & 89 & $8 \mathrm{I}$ & 89 & 90 & 80 \\
\hline
\end{tabular}

Source: Authors based on data from companies' financial statements from 2009 until 2013

An increase in the share of short-term liabilities creates additional pressure on the liquidity and solvency. This is primarily the result of a poor financial operation (high liabilities and unfavourable cost structure), which is why lenders are not inclined to grant long-term loans. 


\section{THE STRUGTURE OF LIABILITIES AND GUARANTEES}

The analysis of government guarantees indirectly provides an insight into the structure of the financial liabilities of publicly-owned road transport companies. This information is mostly scattered throughout the financial statements, annual reports of the Ministry of Finance, the Official Gazette (part of international agreements) etc. Unfortunately, no systematized overview presented in one place exists.

Terms of borrowing. From 2012 until 2014 road transport companies borrowed mainly for programs of construction, maintenance of roads and highways, and for meeting credit obligations. These loans had maturities of seven years, with variable interest rates. The fixed part of the interest rate varied from 4 to $5.6 \%$, whereas the variable portion was usually a six-month or a three-month $(6 \mathrm{M}$ or $3 \mathrm{M})$ Euribor. In order to get a clear image of borrowing costs, the interest costs should be observed together with high bank charges that are generally incurred once - as a percentage of the loan amount. From 2012 until 2014 one-time charges (fees) for I5 loans approved amounted to about EUR I8.9m or HRK I44.6m. There are also additional costs of banks' agency fees that range from EUR 2,000 to 20,000 per year (totalling about EUR 44I,Ooo or HRK 3.36m). Due to additional bank fees the effective interest rate fluctuates within the range of $6-7 \%$.

Currency composition. Out of HRK 57bn of approved guarantees, as much as HRK 53bn is denominated in EUR (over 90\%). ARZ have all guarantees (and credit obligations) denominated in EUR. Credits in HRK are much less represented - only 6.33\% for HC and I.I6\% for HAC. Credit liabilities denominated in USD accounted for $7.9 \%$ and are present only in HAC. This means that financial liabilities of observed companies are exposed to currency risk, and any depreciation of HRK would significantly worsen the debt service conditions (see Figure I.).

Creditors. From 2001 until 2006, the main creditors were the international financial institutions, and rarely domestic commercial banks. From 2006 until 2014 borrowing from domestic and foreign commercial banks was more common, whereas borrowing from international financial institutions was almost non-existent, except for 2010 and $201 \mathrm{II}$ (see Figure 2). For all three observed companies, creditors are domestic and foreign commercial banks and international financial institutions. Domestic commercial banks are exposed in the amount of about HRK 2obn and foreign about Igbn (of which Izbn refers to HAC). Interestingly, foreign commercial banks have not lent to HC. International financial institutions have evenly granted loans and credits to all three companies (a total of HRK 2bn). It is questionable why the state does not to a greater extent borrow from international financial institutions for its infrastructure projects instead of (un)consciously borrowing from foreign and domestic commercial banks (even from the Post Bank) under unfavourable conditions. With the relatively high interest rates it incurs, the state is for those creditors an extremely desirable client.

Maturity of liabilities. According to the analysis of guarantees by maturity it can be concluded that most of the guarantees for credits and loans (29\%) of road transport companies are approved for a period of 5 -IO years (the amount of HRK I6.4bn). The smallest share was approved short-term - up to 5 years ( $8 \%$ or HRK 4.6bn) and long-term - over 20 years (II\% or 6.3bn). From $200 \mathrm{O}$ until 2013, 80 guarantees with average maturity of 12 years were issued to road transport companies. From 2001 until 2007 the average maturity was about 16 years, but in the last two years the average maturity was reduced to about seven years (see Tab. 5 and 6 in the Appendix). High borrowing requirements of road transport companies with high financial risks due to the growth of public debt contributed to the increase in interest rates and reduction of maturities even for borrowings supported with government guarantees. Obviously, the credibility of the state and publicly owned road transport companies has been significantly diminished, so government guarantees have almost no impact on the borrowing conditions (maturities and interest rates). The growth of short-term liabilities of road transport companies is a sign of the increased financial risks related to debt service that will especially be present in the next four years. 
Potential maturity. Road transport companies have created liabilities for the payment of principal and interest (guaranteed by the state) until 2034. Most liabilities mature in 2017, 2018 and 2019 when a total of HRK 17.2bn becomes due in just three years (see Figure 3).

\section{LIABILITIES OF ROAD TRANSPORT COMPANIES, MONETIZATION AND FINANGIAL RISKS}

The liabilities of road transport companies are large. HAC and ARZ are not able to finance those liabilities without support from the government budget. Financial risks of road transport companies are high due to high indebtedness. Road transport companies (especially ARZ) are additionally exposed to interest rate, credit and liquidity risk. Most of the loans are denominated in EUR, which creates negative foreign exchange differences. ${ }^{3}$ Interest rates are variable, exposing road transport companies to additional risks (of changes in interest rates).

In 20I2, the Government decided to look for an extra-budgetary financing model in order to reduce the burden of liabilities due by 20I8. In 20I2, the Government engaged several companies (Erste Group Bank AG, Deloitte Consulting Services Ltd., Wolf Theiss Rechtsanwälte GmbH - Zagreb subsidiary and the company for management of motorways Asfinag International) as consultants for a possible model of monetization of highways (concessions, bonds secured by toll revenue, management contract, the privatization of motorways and privatization of the motorways' operator). The consultants narrowed the selection down to two possible models of monetization - the award of concessions for the management and maintenance of the highways and the issuance of project bonds (which would be repayable with revenue from tolls). Analyses carried out by consultants have shown that the concession model would be the most appropriate. According to this model, motorways would be given in concession for a period of 30-4O years with concession fees ranging from EUR 2.4 to 2.9bn. If the concession period is extended to 50 years then the estimated amount of concession fees could rise to EUR 3.4bn. Such a concession would be the largest foreign investment in the history of the Republic of Croatia. The project followed the Government's Program of restructuring of HAC for the period 2012-2OI5 which envisaged, even before monetization, restructuring of the company aimed at reducing the cost of management and maintenance of motorways as well as the stock of financial liabilities. In line with this model, a special purpose company (HAC-ONC) was established. After the expiry of a period for which a concession to a public good is made (as economic value), the value of the public good returns to the state.

The Government should have carried out the restructuring of companies by 2014 and by October 2014 completed the whole process of selection, conclusion of the contract and received the concession fee from the investor (concessionaire). But it is certain that the process will not be completed in 2014.

All deficiencies and risks that existed, and were not solved in the restructuring process, could affect the potential amount of the concession fees.

The potential risk lies in the fact that highways were being considered for a concession without a comprehensive insight into the conditions of their previous borrowings, the elaboration of interest and principal repayment for financial liabilities up to 2034 as well as the financial and other business risks. Besides these problems, a number of additional risks related primarily to the valuation of road transport companies' assets, financial risks due to legal proceedings and uncertain additional requirements of trade unions still remain.

HAC faces HRK 613 $\mathrm{m}$ in claims in the courts (as of 2013) due to legal disputes. Such claims may have an impact on the operations of companies if there is no estimate of the expected outcome of legal

${ }_{3}$ In 20I3 ARZ faced negative foreign exchange differences in the amount of HRK 88.3m. 
proceedings as well as their expected duration. Therefore, it is difficult to determine the justification of the amount of reservations for potential outflow of funds in this regard.

ARZ is significantly exposed to financial risks. For HC (which is not at the focus of monetization) serious problems of property valuation still remain. HC has not carried out the valuation of roads and buildings since 2000. Due to this reason, the company received a qualified independent auditor's opinion in 2012 and 2013. The problem lies in the fact that HC does not have completely clear property rights ownership of real estate (an ongoing process), nor does it have developed methodology for valuation of public roads (in the process of the development of the methodology) and the valuation assessment. In addition, a significant number of legal proceedings are being conducted against the company (about HRK $328 \mathrm{~m}$ in 2013).

Even the potential risks (weaknesses in the valuation of assets, litigation, etc.) are not an obstacle to investors interested in investing in motorways. However, these deficiencies can affect the final amount of the concession fee. For the Government, it is essential minutely to specify the conditions for approving the concession, and in particular to solve all dilemmas and risks that may affect the amount of concession fees. This requires a significant professional engagement.

Since monetization may affect the amount of debt and the budget deficit, it will be necessary to get the confirmation of the European Commission for its implementation, because Croatia is in the excessive deficit procedure.

\section{CONCLUSION}

In the last two years state companies from the road transport sector have borrowed under relatively unfavourable conditions from both domestic and foreign commercial banks and with maturities of less than seven years. The total amount of road transport companies' debt is - since 20I4 - recorded as a general government debt, which additionally stresses the importance of preparation and adoption of the Public Debt Management Strategy. Within the Strategy the Government should in particular take account of risks associated with financial liabilities of road transport companies and find the most appropriate instruments to refinance those liabilities.

Due to the extremely weak financial position of HAC and ARZ caused by heavy borrowing in previous years, it is almost certain that these companies can not repay the interest and principal without new borrowing. In order to reduce the credit risk, the Government has to continue with the restructuring of road transport companies. Monetization (giving in concession) might be beneficial in this process.

The Government still has to implement a thorough approach in solving the problem of road transport companies. This has to be done since the high liabilities of those companies create a constant pressure on the Government to make further borrowings and increase the general government debt. In the case of the monetization of motorways the Government will get some extra time (3-5 years) to stabilize the public debt and perform significant cuts in the process of restructuring of public companies - to reduce expenditures for employees, subsidies and borrowing. Once the monetization was in place, the Government would still have an obligation to pay the principal and interest of the road transport companies' debt. However, through monetization of motorways (giving concessions to them) the Government would receive a one-time revenue from the concession fee which could cover part of liabilities falling due in the next 3-5 years. If the Government decides not to monetize the motorways, it has to ensure that publicly owned road transport companies are managed in the same way as they would be managed by the private concessionaire. 


\section{APPENDIX}

Table 3.I.

Overview of Croatian Roads' loans from domestic and foreign banks, as of December 31, 2013 (in billion HRK)

\begin{tabular}{|c|c|c|c|c|}
\hline & Maturity & $\begin{array}{c}\text { Total } \\
\text { amount }\end{array}$ & $\begin{array}{l}\text { Current } \\
\text { maturity }\end{array}$ & Long-term \\
\hline \multicolumn{5}{|l|}{ Domestic banks } \\
\hline Privredna banka Zagreb d.d. (PBZ d.d.) & 2015 & 0.04 & 0.03 & O.OI \\
\hline Zagrebačka banka (ZABA d.d.) & 2015 & 0.04 & 0.02 & O.OI \\
\hline PBZ d.d. and ZABA d.d. & 2025 & 0.37 & 0.03 & 0.34 \\
\hline ZABA d.d., PBZ d.d. and SG - Splitska banka d.d. & 2019 & 0.30 & 0.05 & 0.25 \\
\hline ZABA d.d. & $2 \mathrm{O} 23$ & 0.54 & 0.06 & 0.48 \\
\hline PBZ d.d. and ZABA d.d. & 2023 & 0.50 & 0.05 & 0.45 \\
\hline Banca Infrastrutture Innovazione e Sviluppo SpA & 2017 & 0.67 & 0.17 & 0.50 \\
\hline Club long-term loan I & 2022 & I.I8 & & I.I8 \\
\hline Club long-term loan II & 2019 & 0.84 & 0.15 & 0.69 \\
\hline Club long-term loan III & 2019 & I.O2 & 0.09 & 0.93 \\
\hline PBZ d.d. and SG - Splitska banka d.d. & $2 \mathrm{O} 2 \mathrm{I}$ & 0.40 & & 0.40 \\
\hline Erste \& Steiermärkische Bank & 2023 & 0.50 & & 0.50 \\
\hline BKS Bank d.d., Croatia banka d.d. & 2020 & 0.57 & & 0.57 \\
\hline Total liabilities to domestic banks & & 6.98 & 0.65 & 6.33 \\
\hline \multicolumn{5}{|l|}{ Foreign banks } \\
\hline European Investment Bank I & 2027 & 0.38 & 0.03 & 0.36 \\
\hline International Bank for Reconstruction and Development & 2018 & 0.26 & 0.06 & 0.20 \\
\hline European Investment Bank I & 2030 & 0.45 & 0.02 & 0.43 \\
\hline European Investment Bank I & 2036 & O.I4 & 0.00 & 0.13 \\
\hline European Bank for Reconstruction and Development & $203 \mathrm{I}$ & 0.22 & O.OI & 0.20 \\
\hline European Investment Bank I & 2034 & $0.3 \mathrm{I}$ & & 0.31 \\
\hline Total liabilities to foreign banks & & 1.75 & 0.12 & $\mathbf{1 . 6 3}$ \\
\hline Total & & 8.73 & 0.77 & 7.96 \\
\hline
\end{tabular}

Source: Authors based on data from HAC (2013)

Table 3.2.

Overview of maturity of long-term loan commitments of HC and HAC (in billion HRK)

\begin{tabular}{|c|c|c|c|c|c|c|c|}
\hline & 2014 & 2015 & 2016 & 2017 & 2018 & After 2018 & Total \\
\hline Croatian Roads & 0.7 & I.O & I.2 & $\mathrm{I} .2$ & I.O & 3.5 & 8.7 \\
\hline Croatian Motorways & 4.9 & 2.9 & 2.4 & 3.9 & 3.8 & 4.3 & 22.3 \\
\hline
\end{tabular}

Source: Authors based on data from HAC (2013) 
Table 3.3.

Overview of loans for financing of the construction of Motorway Rijeka-Zagreb with government guarantees on December 3I, 2013 (in billion HRK)

\begin{tabular}{|c|c|c|c|}
\hline Loan & Withdrawn & Paid off & Debt principal \\
\hline EIB & 0.06 & 0.02 & 0.04 \\
\hline EBRD & 0.06 & 0.04 & $\mathrm{O} . \mathrm{O} 2$ \\
\hline EIB & $0.2 \mathrm{I}$ & O.OI & 0.20 \\
\hline EBRD & 0.05 & O.OI & 0.04 \\
\hline KFW & O.I3 & 0.04 & O.IO \\
\hline KFW & O.II & O.OI & O.IO \\
\hline DEXIA CREDIT LOKAL & 0.20 & 0.05 & O.I5 \\
\hline $\begin{array}{l}\text { KOMMUNALKREDIT AUTRIJA AG, } \\
\text { INTESA SANPAOLO }\end{array}$ & O.I4 & 0.03 & O.II \\
\hline JP Morgan & O.I4 & & O.I4 \\
\hline ZABA, НAAB, OTP & 0.06 & & 0.06 \\
\hline Total & I.I5 & O.19 & 0.96 \\
\hline
\end{tabular}

Table 5.

Maturity of guarantees granted to the road transport sector from $200 \mathrm{I}$ until 2014 (in billion HRK)

\begin{tabular}{ccc} 
Years & Amount, billion HRK \\
\hline up to 5 & & 4.6 \\
\hline 5 to IO & & I6.4 \\
\hline Io to I5 & I4.6 \\
\hline I5 to 20 & I4.9 \\
\hline more than 20 & 6.3 \\
\hline Total: & 56.8 \\
\hline
\end{tabular}

Source: Authors based on Ministry of Finance's data.

Table 6.

Average maturity of guarantees granted to the road transport sector by years

\begin{tabular}{|c|c|c|c|c|}
\hline Year of issuance & $\begin{array}{l}\text { Average maturity } \\
\quad \text { (in years) }\end{array}$ & HC & HAC & ARZ \\
\hline 2001 & II. 4 & 25.0 & IO.O & 9.0 \\
\hline 2002 & $\mathrm{I} 4.8$ & - & II.7 & 19.5 \\
\hline 2003 & I 4.4 & I5.O & I4.3 & - \\
\hline 2004 & I8.O & II.O & 20.3 & - \\
\hline 2005 & I5.O & I5.5 & I4.5 & - \\
\hline 2006 & 19.9 & 21.3 & I5.O & 25.0 \\
\hline 2007 & 15.6 & $\mathrm{I} 2 . \mathrm{O}$ & I3.3 & 19.0 \\
\hline 2008 & II.O & 15.0 & 8.3 & 14.0 \\
\hline 2009 & 3.3 & 2.0 & 3.5 & 5.0 \\
\hline $2 \mathrm{OIO}$ & 7.3 & IO.O & IO.5 & - \\
\hline $2 \mathrm{OII}$ & I2.I & II.O & $\mathrm{I} 2.3$ & - \\
\hline 2012 & 6.5 & 7.0 & 6.0 & - \\
\hline 2013 & 6.8 & 8.3 & 5.0 & 6.0 \\
\hline Average & I2.O & I2.8 & II.I & I3.9 \\
\hline
\end{tabular}

Source: Authors based on Ministry of Finance's data. 


\section{Figure I.}

Currency structure of government guarantees issued from $200 \mathrm{I}$ until 2014 (in \%)

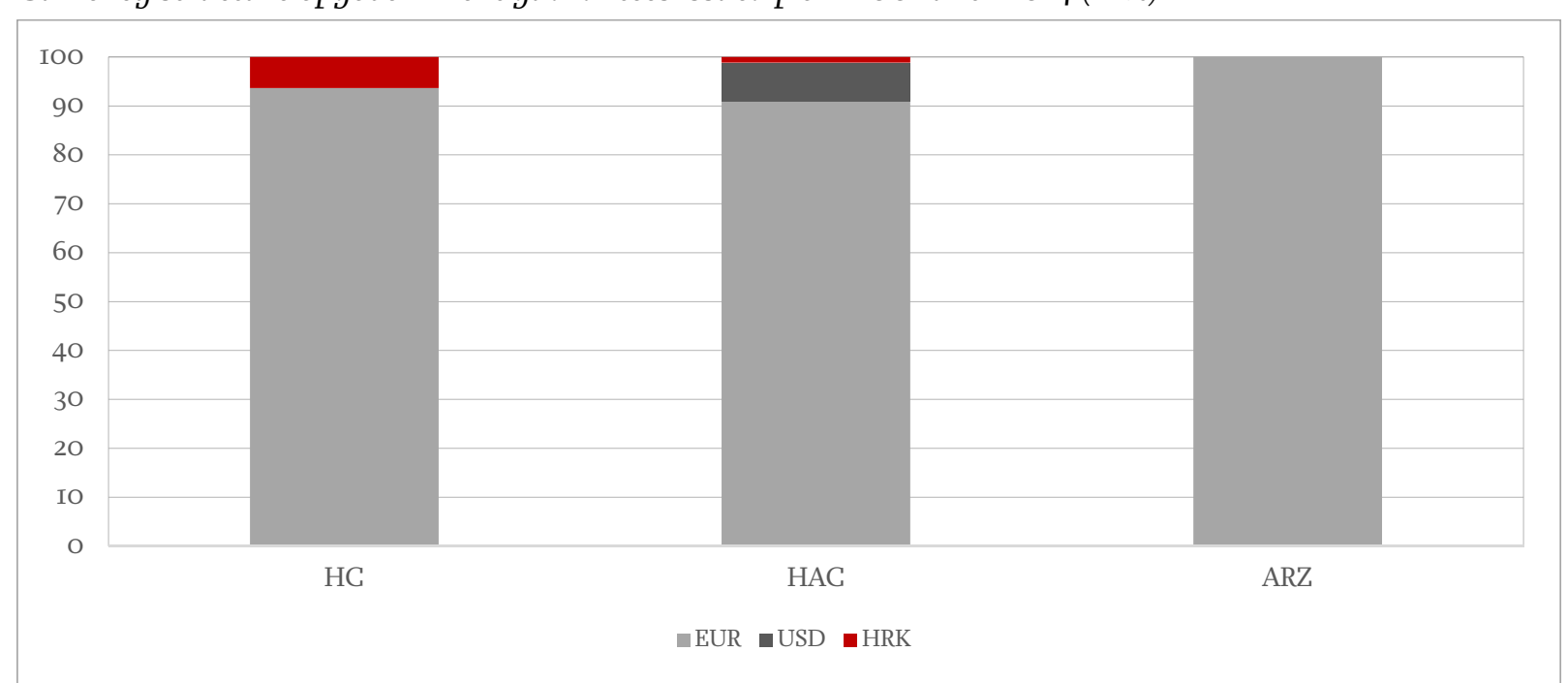

Source: Authors based on Ministry of Finance's data.

\section{Figure 2.}

The structure of the guarantees granted to the road transport sector by type of creditor (in billion HRK)

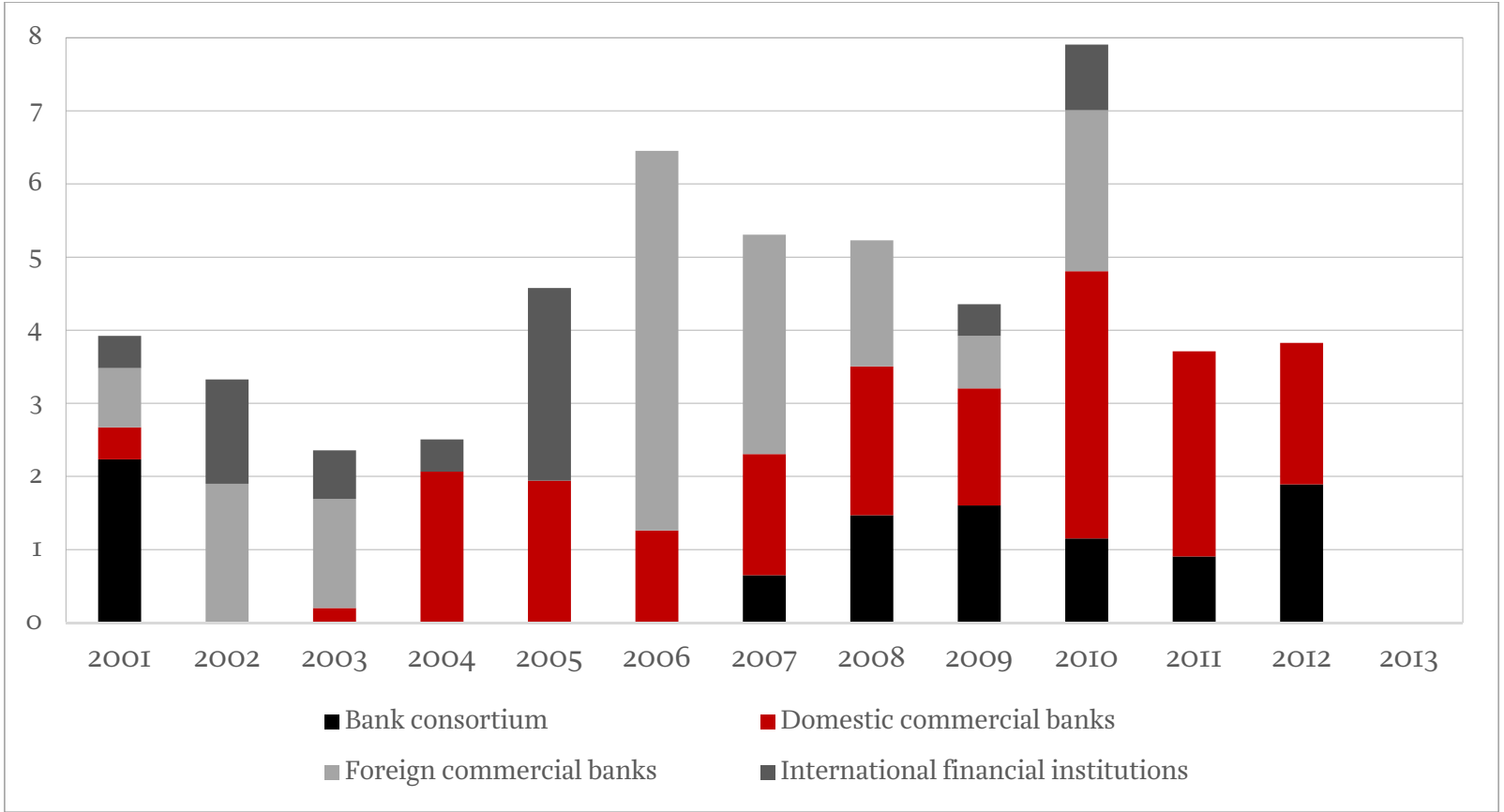

Source: Authors based on Ministry of Finance's data. 


\section{Figure 3.}

Potential maturity of guarantees granted to the road transport sector from 2004 until 2034 (in billion HRK)

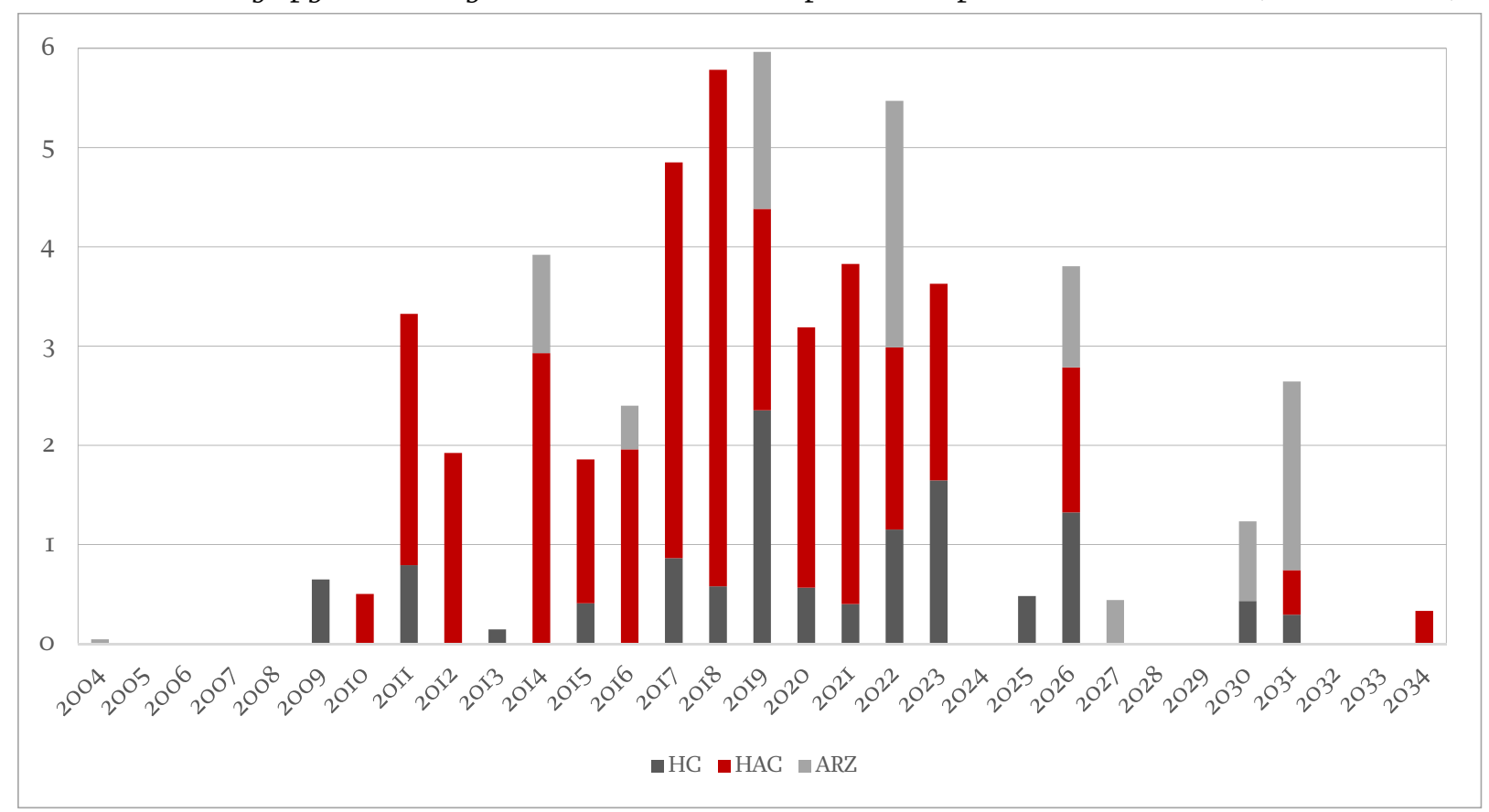

Source: Authors based on Ministry of Finance’s data.

\section{LITERATURE}

ARZ, 20I3. Godišnje izvješće o poslovanju Autoceste Rijeka-Zagreb d.d. u 20I3. Zagreb: Autocesta RijekaZagreb.

Bajo, A. and Primorac M., 20I4. Changes of methodological coverage of public debt and budget deficit in Croatia. Press releases, No. 70.

Bajo, A., Primorac, M. and Andabaka, A., 20II. Osnove upravljanja javnim dugom. Zagreb Institute of Public Finance.

HAC, 20I2. Sažetak programa restrukturiranja za razdoblje 20I2.-I5. Zagreb: Hrvatske autoceste.

HAC, 20I3. Godišnji financijski izvještaji i Izvješće neovisnog revizora za 20I3. godinu. Zagreb: Hrvatske autoceste.

MPPI, 20I3. Monetizacija javnog duga vezano za društva HAC i ARZ - Nacrt konačnog izvješća u Fazi I (radi pregleda $\mathrm{i}$ komentara MPPI). Zagreb: Ministarstvo pomorstva, prometa i infrastrukture.

Petrušić, J., 20I4. Državna jamstva trgovačkim društvima iz sektora cestovnog prometa. Diploma thesis. Zagreb: Faculty of Economics and Business.

Zakon o cestama, NN 84/II, 22/I3, 54/I3, I48/I3, 92/I4. Zagreb: Narodne novine. 